\title{
Przemysław Paweł Grzybowski, Grzegorz Idzikowski: Inni, Obcy - ale Swoi. O edukacji międzykulturowej i wspólnocie w szkole integracyjnej. Bydgoszcz 2018, Wydawnictwo Uniwersytetu Kazimierza Wielkiego w Bydgoszczy, ss. 170
}

Jak słusznie podkreślają autorzy we wstępie: jednym z czynników ułatwiających radzenie sobie z problemami społecznymi będącymi pochodną różnic międzyludzkich - jest edukacja międzykulturowa, która stanowi podstawę do wzajemnego poznania, postaw nastawionych na tolerancję czy akceptację. Przygotowana publikacja sprzyja refleksji nad codziennością w świecie zróżnicowanym kulturowo. Pozwala czytelnikom dostrzec, że prezentowane zagadnienia nie są czymś dalekim, a wręcz przeciwnie - dotyczą każdego z nas.

W wybranym przez autorów motcie Ryszard Kapuściński podkreśla, jak istotna jest wiedza o Innym i jak ważne jest poszukiwanie tych elementów, które są dla nas wspólne lub chociaż są atrakcyjne, a nie wywołujące strach, konflikty czy agresję. Z całą pewnością przygotowana publikacja jest właśnie tego typu pracą, która pozwala poznać/odkryć Innego. Jest to praca tym bardziej cenna, że jej inicjatywa ma charakter oddolny. Zrodziła się w wyniku rozmów prowadzonych po konferencji realizowanej w jednej ze szkół podstawowych w Bydgoszczy. Autorzy uznali, że warto przedstawić szerokiemu gronu odbiorców - często niemającym wiedzy na temat sytuacji funkcjonowania w środowisku zróżnicowanych kulturowo - jak radzą sobie z codziennymi problemami, jak spostrzegają Innych wokół siebie i czym dla osób, które mają świadomość bycia Innymi/bycia z Innymi, jest Inność.

Opracowanie ma charakter poznawczy, dostarcza licznych informacji na temat edukacji międzykulturowej, ale co warto podkreślić, sam jej zamysł, sposób przygotowania, opracowania sprawiają, że czyta się ją z ogromną przyjemnością. Jest to moim zdaniem publikacja warta polecenia szerokiemu gronu czytelników. W sytuacji, gdy tak aktualne jest stwierdzenie Tadeusza Lewowickiego (1994, s. 468), że od wielu lat mamy do czynienia ze swego rodzaju schizofrenią oświatową (polegającą na dystansie dzielącym praktykę edukacyjną od teorii - co przybiera wręcz stan patologiczny), tym cenniejsze jest wydanie publikacji wskazującej, że można znakomicie przygotować pracę będącą dwugłosem zbudowanym przez teoretyka i praktyka. 
Opracowanie zostało podzielone na cztery części - wzajemnie się dopełniające. Całość jest spójna, komplementarna.

Pierwsza część to wprowadzenie teoretyczne przygotowane przez Przemysława Pawła Grzybowskiego, który przybliża czytelnikom podstawowe pojęcia oraz informacje historyczne dotyczące edukacji w środowiskach zróżnicowanych kulturowo. Przystępny język sprawia, że mimo prezentacji trudnych naukowych zagadnień nawet niewprawny w czytanie tego typu tekstów czytelnik zostaje wprowadzony i oprowadzony po najważniejszych terminach. Trafne rozpoczęcie od pojęcia różnicy - budującej nasze własne światy, spostrzeganie innych, pozwoliło autorowi na opis tak ważnych kwestii jak rozróżnienie Swoi, Inni, Obcy. Mając świadomość, kim są odbiorcy, często odwołuje się do emocji, na przykład radzenia sobie z odrzuceniem, gdy sami jesteśmy traktowani z różnych powodów jako Inni (s. 23). Przemysław Paweł Grzybowski dokonuje oswojenia z Innymi/Obcymi poprzez wskazywania sytuacji, w których możemy się z nimi spotkać - i tych bezpośrednich, i tych pośrednich (na przykład poprzez uczestnictwo w kulturze - kontakt z literaturą, filmem czy sztuką plastyczną). Jednocześnie - co jest niezwykle istotne - pokazuje, jakie mogą być korzyści z odczuwanego niepokoju, poczucia zagrożenia w kontakcie $\mathrm{z}$ Innym, bo przecież nie każdy z nich jest „bezpieczny” (ss. 24-25). Ważne jest również zwrócenie uwagi na konsekwencje takich niekorzystnych zjawisk jak rasizm, antysemityzm, nazizm, faszyzm czy komunizm.

Uważam, że ten podrozdział powinien się znaleźć jako obowiązkowa lektura dla nauczycieli i stanowić podstawę do opracowywania autorskich zajęć dotyczących poruszanych zagadnień. Tekst jest napisany tak przystępnym językiem, a jednocześnie stanowi bogate cenne źródło informacji o poruszanych zagadnieniach, że nie powinien się spotkać z zarzutem nadmiernej naukowości i braku przystępności dla nauczycieli praktyków.

W równie przystępny sposób przedstawione zostało zagadnienie związane z rozróżnieniem wielo- i międzykulturowości. Bardzo często (na przykład w mediach) pojęcia te są mylnie przedstawiane, zdarza się, że traktowane są błędnie jako tożsame. Autor, by pomóc czytelnikom w zrozumieniu różnicy, przedstawia powiastkę (ss. 31-33), w której rozstrzygany jest spór uwzględniający perspektywę wielokulturową i międzykulturową (i tu również mamy znakomity materiał do wykorzystania do zajęć praktycznych przez nauczycieli).

Kolejny podrozdział zawiera odniesienia do edukacji w warunkach zróżnicowania kulturowego - tu znajdziemy zarówno odwołania do historii wie- 
lokulturowości (odległej średniowiecznej, jak i bliższej nam XX-wiecznej). Autor wskazuje zarówno na negatywne zjawiska związane z realizacją określonej polityki, jak i przedstawia założenia ideologii stanowiące podstawę do realizacji działań mających na celu segregację, asymilację czy likwidację mniejszości. Opisywana przez autora atrakcyjność realizowania edukacji wielokulturowej sprawia, że mimo krytyki jest to model, który w wielu krajach jest nadal obowiązujący. Alternatywą jest opisany model edukacji międzykulturowej - i tu również otrzymujemy ciekawą dawkę wiedzy o historii międzykulturowości, która nim uzyskała taką nazwę, związana była przede wszystkim z walką, na przykład kobiet, o swoje prawa (s. 41). W tej części niemal gotowym materiałem stanowiącym podstawy wyznaczania założeń teleologicznych i aksjologicznych zajęć/programów są przedstawione cele edukacji międzykulturowej.

Ważne miejsce w rozważaniach zajęła kwestia dotycząca indywidualizmu i wspólnotowości w szkole - z odwołaniami do funkcjonowania w szkole integracyjnej - specyficznej, z założenia zróżnicowanej. Podrozdział, a jednocześnie wprowadzenie teoretyczne - kończy autor trafnie dobranym wierszem Agnieszki Osieckiej „Dziobak”.

Druga część pracy (dopełniona przez Suplement) to zbiór wypowiedzi uczniów, rodziców i nauczycieli. Wszyscy wypowiadający się to osoby związane z wymienioną wcześniej szkołą, a więc osoby mające doświadczenia funkcjonowania w środowisku zróżnicowanym kulturowo. Tytuł rozdziału Jak wielobarwna mozaika jest dobrany adekwatnie do zawartości. Podobnie jak w poprzednią część, autorzy wprowadzają czytelnika w zawartość poprzez przygotowane (w obu przypadkach po trzy) motta.

W krótkim wprowadzeniu Grzegorz Idzikowski zawiera charakterystykę szkoły, której doświadczenia uczniów, nauczycieli i rodziców stały się inspiracją do powstania publikacji (ss. 60-61). Zostali ono poproszeni o pisemne wypowiedzi na temat swoich doświadczeń z Innością. W efekcie Czytelnik ma przed sobą swoisty wielogłos oddający rzeczywisty obraz pewnego wycinka życia społecznego dotyczącego tak wielorako spostrzeganej Inności. Czytając wypowiedzi dzieci, można być zaskoczonym wyjątkową ich dojrzałością, choćby poprzez dostrzeganie przez nich, jak bycie w środowisku zróżnicowanym przyczynia się do wzbogacenia siebie, jak pisze Wiktoria: Gdyby nie klasa integracyjna, nie wiedziałabym jakie sq prawdziwe wartości człowieka i moja wiedza na temat tolerancji bytaby bardzo uboga. Myślę, że ta szkoła ma głównie na celu wychowywać społeczeństwo - w szczególności $w$ tolerancji i empatii (s. 64). Warto również zauważyć, jak celnie w tej wypo- 
wiedzi została określona misja szkoły jako instytucji przygotowującej do życia w świecie zróżnicowanym kulturowo. Równie interesujące są wypowiedzi rodziców - tu już mamy inną perspektywę spojrzenia na Inność. Rodzice dostrzegają Inność w sobie (co niekoniecznie musi wiązać się ze zdefiniowanymi wcześniej różnicami. Inność może oznaczać bowiem specyficzne spostrzeganie świata, ludzi i zdarzeń), wskazują, jak ważne jest przygotowanie dzieci do funkcjonowania w świecie złożonym, zróżnicowanym, opisują wartości wynikające ze świadomego wyboru określonej szkoły (ss. 83-97). Jeszcze inna jest perspektywa nauczycieli (ss. 98-110), którzy nie tylko są w środowisku zróżnicowanym, ale również je kształtują. Budują określone wzory zachowań, uczą funkcjonowania w tym świecie swoich uczniów (czasem ich rodziców). Te teksty uświadamiają, jak ważna jest nie tylko określona praca metodyczna nauczycieli, ale również to, jak istotne są reprezentowane przez nich postawy, wartości, które pozwalają przestrzeń z założenia integracyjną uczynić taką w praktyce (niestety bardzo często mamy do czynienia z pozorną integracją - dzieleniem wspólnie przestrzeni bez bycia razem).

W zakończeniu (niekończącym jednak przygody czytelnika z Innym, Obcym, ale Swoim) autorzy krótko podsumowują prezentowane w opracowaniu wątki, wskazują na różnice w spostrzeganiu pewnych zjawisk przez teoretyków i tych, którzy faktycznie w nich uczestniczą.

Trzecia część to wybór prac dotyczących kwestii szeroko rozumianego zróżnicowania kulturowego. Prace zostały uporządkowane według klucza tematycznego i poprzedzone krótką informacją dotyczącą treści wymienionych publikacji. Jest to bardzo wartościowe źródło danych.

Opracowanie zamyka suplement, w którym zostały przedstawione prace plastyczne uczniów z klas VI i VII Szkoły nr 14 im. Żwirki i Wigury w Bydgoszczy. Prace są efektem konkursu zatytułowanego „Każdy Inny - każdy fajny”. Tak jak pisałam wcześniej - jest to znakomite uzupełnienie części drugiej - tym razem obraz Innego wyrażony został przy zastosowaniu różnych środków plastycznych, i tak jak w wypowiedziach pisemnych mamy do czynienia z ogromnym zróżnicowaniem spostrzegania tematu.

Za jeden z najważniejszych atutów publikacji uważam wyjątkową koegzystencję poglądów autorów, wzajemne powiązania między poszczególnymi częściami, piękne uzupełnianie się wiedzy teoretycznej z doświadczeniami praktycznymi. Opracowanie jest cenne również jako interesujący materiał badawczy w formie zgromadzonych wypowiedzi pisemnych i prac artystycznych. Ich pogłębiona analiza może stać się podstawą do innych, naukowych opracowań. Publikacja jest niemal gotowym materiałem pomocniczym dla 
nauczycieli do realizowania zajęć w szkołach z zakresu edukacji międzykulturowej. Takie tematy jak sygnalizowane jako podrozdział Swoi, Inni, Obcy, czy też Indywidualizm czy wspólnota w szkole mogą być kanwą do realizowania całych cykli zajęć budujących poczucie własnej wartości, tożsamości, okrywania różnic, budowania postaw tolerancji i akceptacji. Wydaje się to ważne zwłaszcza dziś, gdy zróżnicowanie kulturowe stało się elementem codzienności, a jednocześnie tak mocno widoczne są przejawy zachowań wskazujących na brak wiedzy i chęci poznania Innego.

\section{Bibliografia}

Lewowicki, T. 1994. Przemiany teorii i praktyki edukacyjnej - kolejna faza chronicznego kryzysu czy kształtowanie się nowego ładu oświatowego? W: Brzeziński, J. i Witkowski, L. red. Edukacja wobec zmiany społecznej. Poznań - Toruń: Edytor, ss. 464-472.

Anna Szafrańska 